\title{
Nieodzowna utopia wartości. Aksjologiczne znaczenie myślenia utopijnego
}

\author{
An Indispensable Utopia of Values. Axiological Significance of Utopian Thinking
}

\author{
Katarzyna kukaszewska \\ Instytut Filozofii i Socjologii, Akademia Pedagogiki Specjalnej im. Marii Grzegorzewskiej w Warszawie \\ ORCID: https://www.orcid.org/0000-0002-3986-7731•klukaszewska@aps.edu.pl \\ Zgłoszono: 7.03.2020; zrecenzowano: 17.04.2020; zaakceptowano do druku: 17.04.2020
}

\begin{abstract}
Streszczenie: Utopia jest dla człowieka nieodzowna - prowokuje do myślenia, rzuca wyzwania, nie boi się niemożliwego. Dzięki absolutyzacji zdolność do refleksji określa kierunek rozwoju, jego wymiar i znaczenie. Dla aksjologii utopia jest podstawą wcielania w życie wartości o bezwzględnym charakterze, nawet jeśli ich poznanie opiera się na szczególnym rodzaju autonomicznego i intuicyjnego samozobowiązania. Nie można nikogo zmusić do realizowania wartości, ale można nimi zarazić poprzez osobiste zaangażowanie w aksjologiczną utopię, która otwiera na nierelatywność, niewymierność, umiar i zrównoważenie w rozwoju. Utopia wartości przybliża nas do istnienia czegoś, co nie jest wyłącznie relatywne, zależne, uwarunkowane. Teoria wartości bezwzględnych tłumaczy utopijny sens tworzenia zharmonizowanej hierarchii wartości i szukania obiektywnych wartościowań, służących nie tylko pojęciu zrównoważonego rozwoju, lecz także szeroko rozumianej idei wspólnego dobra, wspólnotowego wysiłku.
\end{abstract}

Słowa kluczowe: wartości, utopia, etyka, aksjologia, wartość bezwzględna

\begin{abstract}
Utopia is indispensable for man - it is thought-provoking, challenging, and it defies the impossible. Thanks to absolutisation, the ability to reflect determines the direction of development, its dimension and meaning. For axiology, utopia provides the basis for putting absolute values into practice, even if the process of their cognition is based on a special kind of autonomous and intuitive self-commitment. We cannot be compelled to pursue values, but we can be inspired to cherish them by the example of personal involvement in an axiological utopia, opening us up to non-relativity, immeasurability, moderation, and sustainability in development. The utopia of values brings us closer to the existence of something that is not solely relative, dependent, conditioned. The theory of absolute values explains the utopian sense of creating a harmonised hierarchy of values, and seeking objective valuations, serving not only the concept of sustainable development, but the broadly understood idea of the common good, the community effort.
\end{abstract}

Keywords: value, utopia, ethics, axiology, absolute values 
Przyszłość uważana dziś za prawdopodobna może być tylko gorsza. A ta, która by spetnita nasze życzenia, ma schronienie w Utopii. Tej nie sposób lekceważyć. Albowiem nasza cywilizacja zależy tyleż od przyszłości, co od ropy naftowej; gdy przyszłość się wyczerpie - runie, niczym samolot, któremu zabrakto paliwa.

(Krzysztof Pomian, Kryzys przyszłości)

\section{Wstęp}

Od sceptycyzmu po zachwyt nad utopijnymi tendencjami rozciąga się pole do analizy samej utopii, jako istotnej także w kontekście realizacji wartości we współczesnym świecie. W utopijnym myśleniu tkwi bowiem swego rodzaju dążność do współistnienia realności i idealności będącej przedmiotem aspiracji i jednocześnie katalizatorem aktywności. Sposób, w jaki wartości są utopijne, może być - jak sądzę - interesujący z powodu nieodłącznej obecności tej trudnej do wyjaśnienia idealności, która mimo wszystko posiada walory motywujące do działania. Uważam, że problem utopijnego charakteru wartości może być kluczowym czynnikiem decydującym o sposobie rozumienia współczesnego świata, w tym także idei zrównoważonego rozwoju. Za pomocą pojęcia wartości można spróbować udowodnić, że aksjologiczna utopia jest nam niezbędna; że bez utopijnego, często maksymalistycznego, myślenia człowiek nie wychodzi poza pewne utarte ramy i schematyzm i zostaje często na poziomie biernej akceptacji zastanej sytuacji. „Utopie spełniają funkcje bardzo złożone: służą za łącznik między praktyką a marzeniem, pobudzają zaangażowania ideologiczne, a także ucieczki daleko od rzeczywistości, oświetlają niektóre aspekty tej rzeczywistości, niekiedy maskując inne" (Baczko 2016, 43). Mogą też prowokować do wytężonego wysiłku ze względu na związek myśli z życiem, aspiracji z rzeczywistością, perfekcji z dostępnością. Utopię można na przykład próbować utożsamiać z refleksyjnością (Perkowska-Klejman 2017, 109-123); wtedy "utopista okazuje się synonimem człowieka myślącego” (Szacki 1980, 23). Ja zaś chcę zaproponować, by na utopię spojrzeć tak, jak patrzy się na wartości bezwzględne w aksjologii. Ich przyjęcie zakłada niezgodę na relatywizowanie i apel o wysiłek własnej intuicji, by próbować zrozumieć znaczenie bezwzględności. W tym sensie utopia myślenia oznacza uporczywość twórczego przekraczania pewnej potoczności zastanej, zrelatywizowania wartości i przyznawania prymatu, zwłaszcza tym o charakterze utylitarnym. Nie chodzi tu o szukanie lepszego świata, ale o docieranie do takiego wymiaru, który pozwoli zrozumieć go w kategoriach ogólnoludzkich, a nie wyłącznie jednostkowych, subiektywnych i często przez to trudno komunikowalnych oraz niewspólnotowych. Pilnie dziś potrzebujemy skutecznych odwołań do dobra wspólnego, kategorii wspólnych i nierelewantnych. Brzmi to w równym stopniu nierealnie, jak i nagląco i choć „utopia, która nie musi być pozbawiona rozsądku, ale utopia, jaką znamy, przeżywa [...] kryzys. [...] Nie jest przy tym jasne, czy przesilenie dotyczy wszystkich istniejących i możliwych form myślenia utopijnego?” (Włodarczyk 2017, 61). Być może formą tą może być aksjologiczne szukanie sensu, czyli teoria wartości bezwzględnych. Zakładam, że utopijne myślenie w aksjologii może stać się istotne ze względu na aspiracyjny i rozwojowy charakter realnych działań powodowanych przyjęciem istnienia wartości perfekcyjnych, obiektywnych i absolutnych. Może to właśnie utopie zdolne będą stanowić podstawę oprzytomnienia, zwłaszcza że „w naukach społecznych odgrywają niezwykle ważną rolę, jako że wskazują one na potrzebę zmian i ulepszeń istniejących struktur społecznych" (Płachciak 2011, 89). Skoro proces nieustannych ulepszeń rzeczywistości kończy się konstatacją o nieudolności idei ciągłego wzrostu, to może czas na utopijny plan idei rozwoju zrównoważonego, w służbie 
niepogarszania tego, co jeszcze zostało nieulepszone bezmyślnie. Zakładam, że każda zmiana w świecie wprowadzana jest za pośrednictwem człowieka i to efektem jego zmiany jest ruch w określonym kierunku. Dlatego sądzę, że zdolność do aksjologicznej utopii, akcentującej sensotwórczą rolę wartości perfekcyjnych, ogniskuje dziś problem dystansu i umiaru w obliczu kulminacji chronicznego i bagatelizowanego przesytu.

\section{Utopia}

Utopię rozumiem jako niedościgłość doskonałości, jest ona dla mnie synonimem ideału, alternatywą upomnienia się o inne możliwości, co wcale nie musi być równoznaczne z bliżej nieokreśloną iluzją. Utopia nie musi oznaczać tęsknoty za lepszym światem, ale próbę lepszego rozumienia tego, który już jest; „alternatywa może być nie tylko odrzucaniem istniejącego ładu, lecz również próbą upomnienia się o inne rozwiązania oraz możliwość wyboru odmiennych filozofii życiowych" (Żuk 2008, 53). Inaczej patrząc, "utopię można rozumieć jako obraz, często szczegółowy, upragnionego triumfu woli i rozumu. Rozumu, gdyż każdorazowo ukazuje wyobrażenie działania opartego na przejrzystych mechanizmach lepiej niż inne uporządkowanego społeczeństwa. Woli, ponieważ skuteczna, a jednocześnie trwała interwencja w bieg ludzkich spraw jest w tym wyobrażeniu związana z usprawnianiem całokształtu zdolności życiowych człowieka" (Włodarczyk 2017, 50). Utopia to swego rodzaju „schemat abstrakcyjny. Występuje w pełni jedynie w skrajnych przypadkach, zbliżonych do typów idealnych" (Baczko 2016, 59). Utopia postuluje więc potrzebę stawiania maksymalnych wymagań w obliczu tego, co praktycznie nieosiągalne po to, by idealność tę choć spróbować przybliżyć. I chociaż rzeczywiście „mogą razić przedstawione w niej uproszczenia, sztuczność przykładów, czy też naiwna wiara jej autorów w realizację wyobrażonego świata" (Płachciak 2011, 90), to nie oznacza jeszcze, że wszystkie aspekty utopii są nieskuteczne. $\mathrm{Z}$ perspektywy aksjologii za tę utopijną naiwność można uznać swoistą niezgodę na zrelatywizowanie tego, co faktycznie może być wartością. Obiektywizm wartości może być przyjęciem na siebie jakiejś formy buntu wobec przesady czy przesytu, nadmierności i błędu. Prawdą jest też to, że „na ogół utopistami nazywa się marzycieli oraz ludzi, którzy próbują wdrażać w życie nierealne idee" (Płachciak 2011, 90) i pod tym względem aksjologia także jest utopijna: w sposobie rozumienia wartości kolokwialność decyzji moralnych, jak i potoczność myślenia o wartościach zostają zrównoważone bezwzględną ich cechą, gdy próbujemy utopijnie dowieść, jak Władysław Tatarkiewicz, że istnieje bezwzględna cecha przedmiotu i wcale nie musi odpowiadać mu „żaden stosunek tego przedmiotu do innego" (Tatarkiewicz 1992, 18).

Utopia może być dla człowieka nawet w pewnym stopniu nieodzowna, jeśli założymy, że „tworzenie utopii jest całkowicie naturalne” (Zweiffel 2008, 5) i tak jak „myślenie jest [...] ściśle powiązane $\mathrm{z}$ transcendowaniem biologicznego wymiaru istnienia" (Zweiffel 2008, 5). Wobec tego utopia być może pomaga człowiekowi określić własne bycie w świecie; jak powiedziałby Heidegger: „jest egzystencjalnym ukonstytuowaniem bycia przestrzeni faktycznej możności bycia" (Heidegger 1994, 206). Nie przeczy byciu, ale jest byciem - projektującym, poszukującym, planującym i spełnia się w próbie zrozumienia, wymyślenia. W sposób naturalny wpisuje się w rozwój ludzi i wspólnot, stanowiąc specyficzną formę szukania rozwiązań i alternatyw, a „społeczeństwo bez alternatyw samo sobie uniemożliwia ulepszanie własnych mechanizmów, tkwi w skostniałych schematach, jest zamknięte na nowe pomysły i idee" (Żuk 2008, 53). Dla aksjologii tą rozwijającą utopią napędzającą do zmian może być - w moim przekonaniu teoria wartości bezwzględnych. Najbliższy mi sposób rozumienia bezwzględności to ten w ujęciu zarówno Władysława Tatarkiewicza, jak i Henryka Elzenberga, według którego „wartość obiektywna, i właśnie tylko obiektywna, daje nam to bezcenne dobro: 
sens życia; sprawia, że czujemy się umieszczeni w świecie sensownym" (Elzenberg 1991, 345). Sądzę, że próby docierania do samodzielności wartości są nam pilnie potrzebne, nawet jeśli ich utopijny charakter opiera się wyłącznie na autonomicznej i intuicyjnej próbie dostrzeżenia ich przez człowieka w świecie. Uważam też, że myślenie utopijne jest dla aksjologii wręcz charakterystyczne. Myślenie o wartościach w kategoriach bezwzględnych uznaję za katalizujące dla utopijnego i rozwojowego jednocześnie założenia, że selekcja wartości pozwala uściślić ich charakter, tzn. dostrzec wymiar ich bezwzględności. „Utopistą jest nie każdy, kto myśli o zmianie rzeczywistości. Jest nim natomiast ten, kto rzeczywistość bezwzględnie złą pragnie zastąpić rzeczywistością bezwzględnie dobrą" (Szacki 1980, 30-31). Utopia wartości bezwzględnych przybliża nas do istnienia czegoś, co nie jest wyłącznie relatywne, zależne, uwarunkowane. Można nie móc ustalić stosunku dla wartości obiektywnej, ale to nie oznacza, że jest ona niemożliwa; jest utopijna, ale i nieodzowna. Ma aksjomatycznie niezbędne znaczenie, oparte na zdolnościach sensotwórczych, a przede wszystkim pobudza do działania, poszukiwań i rozwoju, będąc niezgodą na stagnację (Szacki 1980, 209).

Utopia to także swoista alternatywa i szansa na zmianę. Piotr Żuk w książce Spotkania $z$ utopia w XXI wieku zauważa, że „poczucie rozerwania między tym, co jest, a tym, co mogłoby być, tworzy utopię jako alternatywę dla funkcjonującego systemu. Rozważania o możliwych alternatywnych światach pozwalają postawić pytanie o sens realizowanych projektów społecznych" (Żuk 2008, 53). Wobec tego utopia w perspektywie aksjologii nie jest i nigdy nie powinna być ucieczką. To po prostu inna, bardziej perfekcjonistyczna opcja patrzenia na świat ludzkich możliwości w sferze wartości. Tak rozumiana utopia to rodzaj upomnienia się o inne metody i szukanie szans na pojawienie się innych rozwiązań. Więcej nawet: bez utopijnego myślenia o możliwościach i szansach społeczeństwo staje się skostniałe, zhermetyzowane, bez szans na nowe spojrzenia. Krzysztof Pomian sugerował w tekście Kryzys przyszłości, że: „przyszłość uważana dziś za prawdopodobną może być tylko gorsza. A ta, która by spełniła nasze życzenia, ma schronienie w Utopii. Tej nie sposób lekceważyć. Albowiem nasza cywilizacja zależy tyleż od przyszłości, co od ropy naftowej; gdy przyszłość się wyczerpie - runie niczym samolot, któremu zabrakło paliwa" (Pomian 2002, 103) - stąd moja opinia, że dla przyszłości nie jest więc wszystko jedno, czy pozwalamy sobie na utopijne myślenie, czy też nie. Utopia, w tym także utopia aksjologiczna, może bowiem w pewien sposób chronić naszą przyszłość, zapewniać jej kształt dzięki solidnemu paliwu, napędowi do tego, by próbować tworzyć niemożliwe. Być może jest więc tak, że cywilizacja rozpada się, gdy zaprzestaje utopijnego myślenia, a koncentruje się wyłącznie na ropie naftowej; albo też - patrząc z perspektywy idei zrównoważonego rozwoju bez alternatywy utopii mamy brak ropy bez alternatywy.

\section{Utopia jako doskonałość, wartość jako perfekcja}

„Utopie są projektami. Projektami aspirującymi do tego, aby ukazywać stan pożądany, stan idealny" (Perkowska-Klejman 2017, 119), uzasadnić sens dążności do ujęcia perfekcji. Ideał, doskonałość, perfekcja - stanowią dla mnie podstawę dążności działań, podejmowanego trudu, utopijnie nieosiągalnego, ale przynoszącego określone efekty niejako „po drodze”; podobnie rzecz się ma z grecką areté, czyli cnotą, której niedościgłość nie niweluje sensowności. Podobnie bezwzględność, obiektywność i perfekcyjność wartości stanowią dla mnie wyznacznik kluczowy utopijności aksjologicznej. Zdolność do utopii pozwala bowiem w myśleniu aksjologicznym dopuścić możliwość zaistnienia określonej cechy danego przedmiotu, co do której nie musimy ustanawiać żadnej relacji, by uznać ją za ważną; „bezwzględną cechą przedmiotu jest ta jego cecha, która nie jest względna, czyli taka, której nie odpowiada 
żaden stosunek tego przedmiotu do innego czy innych przedmiotów” (Tatarkiewicz 1992, 18); „obiektywna jest zaś cecha, która nie jest subiektywna, czyli której posiadanie nie jest zależne od żadnego podmiotu" (Tatarkiewicz 1992, 24). Wartościowość - jako cecha - może przynależeć do przedmiotu, nawet jeśli nie odwołamy się do zależności i związku z człowiekiem jako podmiotem moralnym. Mogę zapytać za Henrykiem Elzenbergiem: „czy we mnie osobiście przynajmniej nie tkwi gdzieś ta «pocieszająca wiara», że poza wartościowymi rzeczami jest jeszcze wartość sama w sobie, taka platońska, i że jest ponadczasowa?" (Elzenberg 2002, 161). Owszem, tak; ale wiara ta stanowi utopijne sedno przekonania, że pocieszenie w niej otrzymujemy, wyłącznie sposobiąc samych siebie do owej utopii - „Stań się lepszym człowiekiem niż byłeś, a zobaczysz w świecie tym rzeczy, o których ci się przedtem nie śniło” (Elzenberg 2002, 295). Jeśli chodzi zaś o perfekcję wartości, to zgadzam się, że „odróżnienie wartości w znaczeniu ścisłym od wartości w znaczeniu utylitarnym daje wartość perfekcyjną" (Lorczyk 1998, 99). Jakkolwiek obiektywne, bezwzględne i perfekcyjne wartości nie są do końca tożsame ze sobą, to ich status odkrywamy w miarę, jak sami przygotowujemy się na uznanie, że ten utopijny i samodzielny sposób bycia wartości w świecie ma duże znaczenie.

Wartościowanie obiektywne jest tyleż nierealne, co wykraczające indywidualnym wysiłkiem poza aktualną potoczność. W odniesieniu do norm etycznych „utopijność, podobnie jak idealność, jest związana z transcendowaniem oczekiwań ponad aktualnie zachodzace relacje" (Wojewoda 2018, 39) i dlatego równie dobrze „termin «utopijność» można zastąpić określeniem «idealność» [...], ale nie zmienia to ogólnego sensu wykraczania [...] norm poza przeciętne standardy zachowań. Trudno się spodziewać, że będą to normy powszechnie przestrzegane przez osoby lub instytucje - do tej pory przynajmniej tak się nie zdarzało" (Wojewoda 2018, 39). Jest to konstatacja w równym stopniu odnosząca się do etyki, jak i aksjologii: oczywiście, że zdolność do rozróżniania wartości na bezwzględne, obiektywne, perfekcyjne jest utopijną pracą operującą założeniami, że doskonałość, perfekcja ma moc formułowania powinności moralnych. Jeśli jednak faktycznie zastąpimy termin utopijność terminem idealność, możemy przyjąć, że uznanie wartości bezwzględnych za perfekcyjne, idealne pozwala na wykraczanie poza potoczność aktualnego stanu i pospolitą standaryzację myślenia. Rozróżnienie między wartościami względnymi i bezwzględnymi pozwala dopuścić do głosu ten wymiar perfekcji, który może realnie wpływać na niedomagania moralne i zaburzenia w harmonii układania wartości oraz ich pozorny brak komunikowalności. Uważam również, że wartości nie lubią konkurencji i aby ich bezwzględny charakter został przez nas dostrzeżony, konieczne jest utopijne poszukiwanie zrównoważenia i harmonii, które dotyczą także hierarchizowania wartości. Skoro, odróżniając relatywność od bezwzględności, jesteśmy w stanie lepiej układać wartości, to wartość perfekcyjna jest tak samo utopijna jak każda doskonałość, idealność, której poznanie wymaga trudu czynienia samego siebie zdolnym do uzasadnienia znaczenia statusu owej perfekcji. Wobec tego sądzę, że mniejszym problemem jest to, czy wartości bezwzględne są do udowodnienia, niż to w jaki sposób czynimy siebie zdolnymi do ich uznania. „Moc myślenia utopijnego wywodzi się z właściwej mu predyspozycji do wizualizowania przyszłości pod względem radykalnie nowych form i wartości” (Halpin 2003, 40). Sądzę wobec tego, że znaczenie współczesnych koncepcji aksjologicznych w dużej mierze oparte jest na unaocznianiu sobie wartości w ich formie perfekcyjnej i nierelatywnej.

Utopijność wartości przypomina utopijność doskonałości moralnej: wartość perfekcyjna jest tak samo postulatywna jak i moralna doskonałość. „Tutaj mamy do czynienia z wewnętrznym pęknięciem między tym, co postulowane, a tym, w jaki sposób faktycznie postępujemy. Niespójność między regułą a działaniem dotyczy 
jednostek i społeczności. Podmiot odczuwa to jako wezwanie wynikające z poznania świata wartości ujętego w duchu powinności czynu - «powinieneś postępować inaczej niż aktualnie jest»" (Wojewoda 2018, 43). Podobnie rzecz wygląda w aksjologii rozróżnienie między wartością utylitarną a perfekcyjną pozwala utopijnie zakładać, że jest w związku z tą wiedzą jakiś plan do wykonania. Skoro „podmiot odczuwa to jako wezwanie wynikające z poznania świata wartości” (Wojewoda 2018, 43), to możemy uznać, że ta wizja możliwości staje się zobowiązująca, jakkolwiek byłaby wprost utopią. Zgadzam się w pełni, że na tym między innymi polega właśnie paradoks intelektualizmu etycznego - „znajomość zasad dotyczących dobrego postępowania nie daje gwarancji ich przestrzegania. Tutaj należy uwzględnić jeszcze czynnik woli, czyli dobrowolnego uznania lub odrzucenia postulowanych norm etycznych. Trudno o pewność, że taki proces będzie zawsze zachodził, pozostaje on jedynie postulatem" (Wojewoda 2018, 44). Sama wiedza o dobru nie wystarczy, by dobrze postępować, ale dobrowolne uznanie wiedzy o dobru stanowi sprzężenie dla ludzkiej woli. Uznanie, że coś jest wartością, w bezwzględny sposób ukierunkowuje w działaniu i przekonuje do zasadności paradoksalnego starania się o to, czego nie można udowodnić, ale co realnie zmienia postępowanie na lepsze. Utopia wartości opiera się także i na tym paradoksie.

Człowiek, któremu zadano wartości, jest w pewnym stopniu utopistą, ale nie odrealnionym fantastą. Łukasz Zweiffel w wydanej w 2008 r. książce pt. Utopia. Idealna odpowiedź na nieidealna rzeczywistość pisał, że „istnieje związek ideału utopijnego z doświadczeniem. W planowaniu występuje ciągłe powracanie do źródła - utopii, ale ten powrót zapośredniczony jest zawsze w działaniu." (Zweiffel 2oo8, 14). Wobec tego skoro utopia wartości bazuje na postulacie troski o ważność, którą definiujemy bezwzględnie, i skoro status danej wartości jest niezależny, samodzielny, to doceniając ten wspólny aksjologicznie wymiar, akcentujemy także zdolność do obiektywizacji i absolutyzacji wartości. Wobec tego planowanie jest zawsze pewną utopią, a zakładanie, że istnieją wartości o bezwzględnym charakterze, również nią jest. Niemniej powracanie do takiego założenia nie dzieje się w próżni, zapośrednicza je nasze działanie. „Bo nie sposób oddzielić wartości od świata i człowieka. [...] Wartości są po prostu życiem, jego esencją, jego Prawdą, pierwiastkiem wiecznym, energią doskonalenia i energią doskonalącą" (Pasterniak 1995, 25). Ich analiza jest zawsze doświadczaniem świata, w którym żyjemy. Jednak „źródłem kryzysu wartości nie jest zanikanie wartości, ale funkcjonowanie «nadmiaru» równorzędnych hierarchii wartości, które «absolutyzują» swoje wartości naczelne i redukują wszystkie inne do tych wyróżnionych" (Zuziak 2012, 295), zamiast określać obiektywnie wspólny charakter wartości jako takich. Gdy potrafimy bowiem określać wartości jako niezależne, ich mnogość przestaje być kolekcją subiektywną, uzależnioną od podmiotu. Udzielenie wartościom statusu bezwzględnego pozwala określać plan dążeń do perfekcji jako esencji naszych codziennych starań. Jest to jednak kwestia dobrowolnego uznania, zdolnego wpływać powinnością na praktykę życiową; jesteśmy wtedy skłonni uznać, że wartości nie lubią porównań, nie lubią też tłoku, nadmierności, przesytu. Z braku doświadczenia można nauczyć się bowiem więcej, niż z nadmiaru, a selekcja wartości daje nieporównywalnie więcej, niż ich kolekcja. To nie jest wszystko jedno, jak wartościujemy i czy ma to charakter obiektywny, czy też opiera się wyłącznie na subiektywizmie ocen moralnych. Sposób, w jaki czynimy siebie zdolnymi do uchwycenia bezwzględności wartości spaja doświadczenie z celem, działanie z dążeniem, faktyczność z utopią. „By świat uczynić doskonalszym, nie trzeba [...] «rozbijać go na kawałki», by go znów «odbudować jako bliższy pragnieniom serca». Przeciwnie: trzeba zespolić jego dwie obce sobie, ale aksjologicznie na siebie zdane połowy. Odbudować świat jako doskonalszy to 
przedmiotowość przepoić podmiotowością, z rzeczy zewnętrznych uczynić przejawy i symbole treści wewnętrznej" (Elzenberg 2002, 231). Takim staraniem jest w aksjologii troska o dobra bezwzględne, „taką utopią jest Najwyższe Dobro, które wyznacza cel, całą przyszłość" (Zweiffel 2008, 17).

\section{Aksjologiczny sens utopii, utopijna sensowność aksjologii}

Możliwość, dostępność nie są - jak wiadomo - często przekuwane w faktyczność, podobnie jak oczywistość wcale nie oznacza powszechnego uznania. Bezwzględność wartości jest nie do udowodnienia, wiedza o wartościach bez poczucia powinności wcale nie przekłada się na wartościowe postępowanie; dlatego plan wartości jest utopijny, zakłada bowiem szczególną atencję dla doskonałości i zobowiązujący charakter jej akceptacji. Jest w tym założeniu maksymalizm wymagań własnych i osobiste zobowiązanie wobec aksjologicznego planu. Pod tym względem „utopia jest kresem myśli ludzkiej, jest jej absolutyzacją. Staje się ona w ten sposób synonimem moralnego ideału" (Zweiffel 2008, 17), postulując ważność świadomego dążenia do zmiany na dobre. Uważam, że dla aksjologii absolutyzacja wartości jest tak samo niezbędna, jak utopia dla rozwoju myśli ludzkiej. Ponieważ „projekty dotyczące lepszej przyszłości, nowego ładu społecznego, poprawy jakości życia mieszkańców bądź korekty natury ludzkiej mają w pewnym sensie charakter utopijny" (Wojewoda 2018,37 ), to absolutyzacja wartości i obiektywizacja wartościowań - w kontekście chociażby ignorancji idei zrównoważonego rozwoju i etyki globalnej - pozostawiają wciąż otwarte pytania, w jaki sposób utopia zdolna jest z postulatu perfekcji czynić jakąkolwiek zmianę. Rozwój zrównoważony jest i będzie utopijny, także w proponowanej przeze mnie optyce aksjologicznej, ze względu na to, że akcentuje znaczenie tworzenia zharmonizowanej hierarchii wartości, czyli rozsądku w porządkowaniu tego, co ma wspólną ważność. Pytanie: na ile ta utopia może się jeszcze rozwijać.
Utopia „rodzi się ona wtedy, gdy w świadomości ludzkiej zjawia się rozdarcie między światem, który jest, a światem, który w danym momencie jest tylko do pomyślenia, a i to tylko dla nielicznych" (Szacki 1980, 105-106). Twierdzę, że w aksjologii tym sposobem myślenia jest teoria wartości bezwzględnych i stanowi swoistą próbę wykorzystania zdolności człowieka do utopii. W kontekście dobra wspólnego utopia określa zasadność idealności w myśleniu i celowości w działaniu, zwłaszcza w obliczu załamania się uzdolnień do generowania sądów odwołujących się do kategorii bezwzględności, obiektywności, wspólnotowości. Jak pisze Zbigniew Hull, „jeśli nawet wizja zrównoważonego rozwoju jest wizją w dużym stopniu utopijną, to taka utopia - ukazująca możliwości innego sposobu użytkowania przyrody oraz społecznego i indywidualnego życia - jest nam dzisiaj potrzebna" (Hull 2003, 24). Więcej nawet: skoro „utopia postrzegana jako ideał jest najpowszechniejszym pierwiastkiem $\mathrm{w}$ świecie ducha, jest obecna we wszystkich teoriach stworzonych przez człowieka, w wszelkiej wiedzy i twórczości" (Zweiffel 20o8, 17), to odwołanie się do niej, zwłaszcza w sytuacji kryzysu, uważam za tyleż niewykonalne, co konieczne i słuszne. Jeśli uznamy, że utopia jest sednem wszelkiej ludzkiej twórczości i jej pierwiastek zawsze tkwi w rozwoju ze względu na zdolność do absolutyzacji, to podejmowanie utopijnych prób oznacza poruszanie się w słusznym kierunku. „Nasza historia nigdy nie dzieje się bez nas" (Kozłowski 20o8, 219), a ponieważ „każdemu okresowi historycznemu towarzyszy wyobrażenie, które go transcenduje" (Zweiffel 2008,17 ), to jesteśmy odpowiedzialni za ideę, którą absolutyzujemy. Zwłaszcza, że „nie stać nas na obojętność wobec teraźniejszości i przyszłości, która się wyłania" (Kozłowski 2008, 219) i być może nie możemy sobie już pozwolić na brak utopii w naszym życiu, bez względu na to, jak bardzo odrealnioną wydaje się nam być to potrzebą.

To prawda, że „utopista może mylić się zarówno w diagnozie, jak i w prognozie, ale 
jego wysiłek nie traci z tego powodu sensu, chodzi bowiem nade wszystko o wykazanie, iż nie można pogodzić się z rzeczywistością i trzeba szukać jakiegoś ideału" (Szacki 1980, 209), głównie dlatego, że nie mamy innego wyjścia, jak przyznać, że bez utopii, w tym także aksjologicznej, nie jesteśmy w stanie poradzić sobie z dosłownością zjawisk, których relatywność skutecznie burzy nasze wysiłki opisywania ich we wspólnych kategoriach. Relatywizm jest tak banalny do udowodnienia, że postulat bezwzględności wartości faktycznie brzmi przy nim jak utopia. Niemniej dla utopisty wartości - idea wspólnego dobra czy idea zrównoważonego rozwoju zawsze będzie oczywista i zrozumiała, bo działają w niej te same mechanizmy porządkowania świata wizją ideału. Tadeusz Kotarbiński stwierdził kiedyś w tekście dotyczącym etyki niezależnej, że idealiści lepiej nauczają etyki (Kotarbiński 1958, 3-13). Parafrazując te słowa, stwierdzić można, że utopijne idee lepiej nauczają świat rozwoju, niż zachowawcze, fundujące wyłącznie status quo, relatywne założenia. Zwłaszcza, kiedy chodzi o strukturę umiarkowania i harmonii w doborze i selekcji wartości w dobie przesytu. Od czasu Arystotelesa wiadomo, jakie znaczenie ma idea umiaru - pytanie: czy jest ona wobec tego tak nierealna? Otóż uważam, że jest tak utopijna i to tak bardzo, że aż niezrozumiana. Tymczasem umiar jako idea - jest planem i utopijnym, i niezbędnym jednocześnie, tak jak wartość nierelatywna. Wartości są nośnikami sensu i jeśli utopie mają go mieć, to muszą w jakimś stopniu dotyczyć sfery aksjologicznej. Twierdzę, że utopiom sens nadaje aksjologia, sama będąc planem utopijnego prezentowania bogactwa znaczeń wartości bezwzględnych, których zrozumienie i realizacja w świecie są nam społecznie bardzo potrzebne. Wartość bezwzględna pozwala bowiem ludziom na myślenie kategoriami wspólnymi, przybliżając tym samym do zdolności wydawania raczej opinii wartościujących niż sądów oceniających, z założenia jednostkowych i subiektywnych.

\section{Zakończenie}

Podsumowując, aksjologia jest utopijna w maksymalizmie swojego planu, ale nie w jego niemożliwości. „Plan utopistyczny jest metodą kształtowania ładu dynamicznego, który zawsze można poprawić, uzupełnić i poddać nowej reinterpretacji” (Płachciak 2011, 95). Nie chodzi o idealizm tkwiący w założeniach, których realność i skuteczność jest na tyle wątpliwa, że aż utopijna: „plany oraz przyświecające im założenia nigdy nie powstają w próżni, [...] są rozciągnięte między tym, jak jest, a tym, jak być powinno. Dlatego szlak każdego myśliciela będzie zawsze przebiegał wśród tego, co go otacza, kierując jednak plan naprawy ku fundującemu ideałowi" (Zweiffel 2008, 18). Dlatego ze względu na uznanie pewnego układu ważności decydujemy się na starania, a nie $\mathrm{z}$ powodu oderwania ich od pospolitości spraw, które miałyby być niegodne perfekcji. Wartość perfekcyjna jest myślowo absolutyzacją, ale ma realny wpływ na zdolność ukierunkowania działania. Podobnie „idea rozwoju zrównoważonego nie jest też typem myślenia utopistycznego, w którym zakłada się, że wyobrażona rzeczywistość jest nierealna" (Płachciak 2011, 94); ideał jest w pewnym stopniu osiągalny właśnie dlatego, że zakorzeniamy go w doświadczeniu. Jest w tym idealizmie dużo więcej skuteczności niż w ideologii efektywności, a przecież „podporządkowywanie założeń idei rozwoju zrównoważonego neoliberalnym reżimom niekończącej się akumulacji kapitału i wzrostu gospodarczego niewątpliwie przybiera postać ideologii o charakterze zachowawczym" (Płachciak 2011, 98).

Wartości o charakterze bezwzględnym wydają mi się być bezcennym argumentem w dyskusji nad ideą rozwoju zwłaszcza, że utopia aksjologicznej bezwzględności ma tak samozobowiązujący charakter. To znaczy, że „jeśli mi ktoś pokaże obraz Rembrandta, nie stanowi to dla mnie powodu, by się kusić o malowanie jak Rembrandt, bo to jest rzecz zdolności malarskich, ale gdy mi stanie przed oczy obraz męstwa albo sprawiedliwości, mam prosty i nieodwołalny 
obowiązek uczynienia wszystkiego, by samemu, w miarę możliwości, stać się mężnym i sprawiedliwym" (Elzenberg 1991, 138-139). Kontakt z obiektywnym, sensotwórczym sposobem bycia wartości ma powinny charakter: wartość sama w sobie czyni zobowiązania, które człowiek przyjmuje tym chętniej, im bardziej zrozumiała jest dla niego dana wartość. „Nie mniejszą jednak siłę nakazu ma każda wielkość konkretna, odczytana z żywych dążeń i czynów" (Elzenberg 1991, 139), ponieważ utopia wartości to plan maksimum w świecie jak najbardziej realnym. Twierdzę więc, że „nadszedł czas na powrót do utopijnego myślenia" (Bregman 2018, 25) także w wymiarze aksjologicznym. Ze względu jednak na to, że „brak gwarancji obiektywizmu aksjologicznego i etycznego stawia nas wobec osobistej odpowiedzi na wartości" (Wiśniewski, 2009, 27), musimy pamiętać, że tak naprawdę zrozumieć wartość jako bezwzględną, to przede wszystkim starać się samemu być gotowym na takie rozpoznanie: „być coś wartym” - to, u samej podstawy, mieć skłonność do zwracania się twarzą ku rzeczom wartościowym, „szlachetnym" (Elzenberg 2002, 310). Dlatego też wartości obiektywne nie są niemożliwe - są utopijne i w utopii swej fundamentalnie nieodzowne człowiekowi, zwłaszcza w obliczu przeakcentowania nieuchronnością wszelkich uwarunkowań i zależności.

\section{Bibliografia}

Baczko, Bronisław. 2016. Światła utopii. Warszawa: IFIS PAN.

Bregman, Rutger. 2018. Utopia dla realistów. Warszawa: Czarna Owca.

Elzenberg, Henryk. 1991. Z filozofii kultury. Kraków: Znak.

Elzenberg, Henryk. 2002. Ktopot $z$ istnieniem. Aforyzmy w porzadku czasu. Toruń: Wydawnictwo UMK.
Halpin, David. 2003. Hope and Education. The Role of the Utopian Imagination, London-New York: Routledge Falmer.

Heidegger, Martin. 1994. Bycie i czas. Warszawa: PWN.

Hull, Zbigniew. 2003. „Filozofia zrównoważonego rozwoju". W Filozoficzne $i$ społeczne uwarunkowania zrównoważonego rozwoju, red. Artur Pawłowski, 15-25. Lublin: PAN.

Kotarbiński, Tadeusz. 1958. „Zasady etyki niezależnej”. Studia filozoficzne 2 (1): 3-13.

Kozłowski, Michał. 2008. "Granice utopii”. W Spotkania z utopia w XXI wieku, red. Piotr Żuk, 215-219. Warszawa: Oficyna Naukowa.

Lorczyk, Andrzej.1998. „O nadwartości, powinności i sensie. Prolegomena rekonstrukcji późnej aksjologii Elzenberga". W Człowiek wobec wartości w filozofii Henryka Elzenberga, red. Andrzej Lorczyk, 93-126. Warszawa: Polskie Towarzystwo Filozoficzne Stakroos.

Pasterniak, Wojciech. 1995. Przestrzeń edukacyjna. Zielona Góra: Wydawnictwo WSP.

Perkowska-Klejman, Anna. 2017. „Utopia i refleksyjność." W Utopia a edukacja, t. 2, red. Rafał Włodarczyk, 109-123. Wrocław: Instytut Pedagogiki Uniwersytetu Wrocławskiego.

Płachciak, Adam. 2011. „Utopistyczny wymiar rozwoju zrównoważonego". Annales. Etyka wżyciu gospodarczym 14 (1): 89-98. Łódź: Wydawnictwo Uniwersytetu Łódzkiego.

Pomian, Krzysztof. 2002. Oblicza XX wieku: Szkice historyczno-polityczne. Lublin: UMCS.

Szacki, Jerzy. 1980. Spotkania z utopia. Warszawa: Iskry.

Tatarkiewicz, Władysław. 1992. Pisma z etyki i teorii szczęścia. Wrocław - Warszawa - Kraków: Zakład Narodowy im. Ossolińskich.

Wiśniewski, Ryszard. 2009. „O niektórych pożytkach studiów nad aksjologią i etyką Elzenberga". W Elzenberg - Tradycja i wspótczesność, red. Włodzimierz Tyburski i Ryszard Wiśniewski, 19-30. Toruń: Wydawnictwo Naukowe UMK.

Włodarczyk, Rafał. 2017. „O rozczarowaniu utopią i myśleniu krytycznym". W Utopia a edukacja, t. 2, 
red. Rafał Włodarczyk, 49-63. Wrocław: Instytut Pedagogiki Uniwersytetu Wrocławskiego.

Wojewoda, Mariusz. 2018. „Etyka jako utopia społeczna. Analiza w perspektywie filozofii wartości”. Er(r)go. Teoria-Literatura-Kultura 36 (1): 37-50.

Zuziak, Władysław. 2012. „Czy aksjologia może przezwyciężyć ponowoczesny kryzys wartości?” Przeglad Filozoficzny - Nowa Seria 21, 2(82): 295310. https://doi.org/10.2478/v10271-012-0058-6.
Zweiffel, Łukasz. 2008. Utopia. Idealna odpowiedź na nieidealna rzeczywistość. Kraków: Wydawnictwo Naukowe Akademii Pedagogicznej.

Żuk, Piotr. 2008. „O pożytkach z utopii w życiu publicznym i naukach społecznych". W Spotkania z utopiq w XXI wieku, red. Piotr Żuk, 49-60. Warszawa: Oficyna Naukowa. 